\title{
GÉPI LÁTÁSON ALAPULÓ DEMONSTRÁCIÓS ALKALMAZÁSOK FEJLESZTÉSE
}

\author{
Forgács Zsófia \\ PhD hallgató, Miskolci Egyetem, Automatizálási és Infokommunikációs Intézet \\ 3515 Miskolc, Miskolc-Egyetemváros, e-mail: forgacs.zsofia@uni-miskolc.hu
}

\begin{abstract}
Absztrakt
A gépi látás rendszerek egyre gyakoribb alkalmazása tapasztalható a gyártásban, különösképpen a minőség-ellenőrzés területén, annak megbizhatósága, gyorsasága, pontossága és ismételhetösége végett. A negyedik ipari forradalomban támasztott irányelvek szerint a gyártás hatékonysága az adatok következetes gyüjtése- és feldolgozása által növelhetö, melyben fontos szerepet kapnak a korszerü automatizálási technológiákkal támogatott intelligens gyártási folyamatok. A cikkben a gépi látás rendszerek tervezéséhez szükséges ismeretek összefoglalása után oktatási céllal készült alkalmazási példák és projektfeladatok kerülnek bemutatásra.
\end{abstract}

Kulcsszavak: gépi látás, ipari automatizálás, oktatás, Ipar 4.0, LabVIEW

\section{Abstract}

There is an increasing use of machine vision systems in manufacturing, especially in the field of quality control, due to its reliability, speed, accuracy and repeatability. According to the directives of the Fourth Industrial Revolution, production efficiency can be increased through consistent data collection and data processing, and by intelligent manufacturing processes supported by state-of-the-art automation technologies. After summarizing design process of machine vision systems, the article presents project tasks and application examples for educational purposes.

Keywords: machine vision, industrial automation, education, Industry 4.0, LabVIEW

\section{Bevezetés}

Az Automated Imaging Association (AIA) a világ legnagyobb gépi látással foglalkozó kereskedelmi egyesülete, amely több, mint 350 taggal rendelkezik, köztük rendszerintegrátorokkal, gépi látás komponens gyártókkal, szoftverszolgáltatókkal és forgalmazókkal. Az AIA szerint a gépi látás magába foglal minden olyan ipari és nem ipari alkalmazást, amelyben az alkalmazott hardver és szoftver kombinációja alkotta rendszer képek rögzítésén és feldolgozásán alapuló funkciókat hajt végre [1].

A gépi látás rendszerek fejlesztése több tudomány- és szakterületet érintő ismereteket és a potenciális alkalmazási területek azonosítását követeli meg. Bár a gépi látás rendszerek különféle technológiákat alkalmazhatnak, jellemzően hasonló lépéseket követnek a képrögzítéstől a beavatkozásig. Ezek a lépések tipikusan az optikai adatgyüjtés a jelenet (angolul „scene”) korlátozásainak figyelembevételével, az előfeldolgozás, a szegmentálás, a vizsgált jellemző, mint képi információ kinyerése, az osztályozás és/vagy képelemzés, majd végül a döntéshozatal és beavatkozás [2].

A kamerák és feldolgozóegységek legújabb technológiai fejlesztései, valamint a hardverköltségek csökkenése felgyorsíthatják a gépi látás alkalmazását az iparban, sok vállalatnak azonban továbbra is korlátozott hozzáférése van a gépi látással kapcsolatos ismeretekhez [2]. Az oktatásban a témakör elméleti alapismereteinek összefoglalása mellett nagy hangsúlyt szeretnénk fektetni a gépi látás alkal- 
mazások megvalósításának gyakorlati oldalára, a megfelelő megvilágítási technikával támogatott képi adatgyüjtéstől az irányítástechnikai rendszer által végrehajtott beavatkozási műveletig.

\section{Az ipari gépi látás rendszerek tervezési szempontjai}

A gépi látás rendszerek a képrögzítéshez az ipari kamerákon belül védett digitális szenzorokra támaszkodnak, speciális optikával, így a számítógépes hardver és szoftver képes feldolgozni, elemezni és mérni a különböző jellemzöket a döntéshozatalhoz [3]. A gépi látás egyre széleskörübb felhasználása figyelhető meg mind az iparban, mind az oktatási, kormányzati vagy katonai alkalmazásokban [1].

A negyedik ipari forradalomban az intelligens gyártási folyamatok megjelenésével egyre növekszik az igény a gyártási folyamatok professzionális vizsgálata és a minőségi adatok iránt, ezért válik egyre fontosabbá a gépi látás szerepe az ipar számos területén. A gépi látáson alapuló alkalmazások köre jelentősen megnőtt az elmúlt években, erre egy példa a 2D képfeldolgozásról a háromdimenziós rendszerekre történő fejlődés. A gépjármügyártásban a 3D rendszerek összetett geometriákat, például öntvényeket vizsgálnak. Az optikai rendszerek nemcsak a legkisebb hibákat észlelik, hanem értékes adatokat szolgáltatnak, amelyek a gyártási folyamat optimalizálására használhatók fel [3].

A gépi látáson alapuló rendszerek tervezési módszertana már számos tanulmányban összefoglalásra került. Egy általunk vizsgált forrásban [4] a gépi látás rendszer első tervezési lépése a jelenet vizsgálata és az alapján a megfelelő megvilágítási technika és optikai rendszer kiválasztása. A második lépésben az optikai adatgyűjtés történik a (jellemzően CCD vagy CMOS) képérzékelőkkel a megvilágított jelenetről, a harmadik lépés a digitalizálás, mely során a képrögzítés és -megjelenítés kerül elvégzésre. Az utolsó lépés a képfeldolgozás, amely során olyan módosításokat hajtunk végre a digitális kép pixelértékein, hogy megfelelö formát kapjanak a későbbi müveletekhez.

A tervezési módszerünk első lépése a jelenet vizsgálata és a rendszer környezetének előkészítése, azonban a megvilágítás tervezését csupán az optikai paraméterek meghatározása és a képrögzítő eszköz kiválasztása után tartjuk célszerünek. Ennek az oka, hogy a képrögzítés módja és az optikai rendszer fizikai kialakítása nagymértékben befolyásolhatja az alkalmazott megvilágítási technika hatékonyságát. Az adatgyüjtés és megvilágítás tervezése után fontos szempont, hogy az optikai adatok digitalizációja és továbbítása hogyan, milyen interfészen keresztül történik a feldolgozóegység felé. Az utolsó lépés a képfeldolgozásért és egyéb irányítástechnikai feladatokért felelős szoftver tervezése és az ezt végrehajtó vezérlőegység kiválasztása, figyelembevéve a kiválasztott képrögzítő eszköz és a rendszert felépítő további eszközök jellemzőit és a vezérléssel szemben támasztott követelményeket. A következő alfejezetekben a gépi látás rendszerek tervezéséhez szükséges alapismereteket foglaljuk össze.

\subsection{A képrögzítés folyamata}

A rendszerünk meghatározó eleme a kamera, melynek kiválasztásánál számos szempontot kell figyelembe vennünk. Elsőként az optikai rendszer paramétereit sorra véve meghatározzuk a szükséges szenzorméretet és felbontást, a munkadarab távolságának függvényében a megfelelő fókusztávolságot, majd ezután az alkalmazáshoz mérten a képrögzítés módját, végül pedig megvizsgálva a lehetséges kamera típusokat és interfészeket kiválasztjuk az alkalmazásunkhoz legjobban illeszkedő eszköztípust.

\subsubsection{A kamerabeállítás paraméterei}

A kameraszenzorok kétdimenziós pixeltömböket tartalmaznak, melyek a fény intenzitását érzékelik, ezek a mérési adatok pedig sorosan vagy párhuzamosan egy kimeneti regiszteren keresztül továbbíthatók a feldolgozóegység felé. A szenzor felbontását a vizsgált objektum legkisebb jellemzőjének mérete 
és a látómező segítségével határozhatjuk meg. A fókusztávolság (f) az objektív jellemző paramétere, a nagyítás mértékének meghatározására használt mérőszám, melyre a munkatávolság, a látómező és a szenzorméret is hatással lesz. Mivel a lencsék csak bizonyos szabványos fókusztávolságokkal elérhetök (pl. $6 \mathrm{~mm}, 9 \mathrm{~mm}, 12,5 \mathrm{~mm}$ ), ezért az eszköz kiválasztását követően a munkatávolságot úgy kell beállítanunk, hogy a vizsgált munkadarab fókuszban legyen [5].

\subsubsection{Képrögzítési módszerek}

Alapvetően két technológiát különböztethetünk meg, az area scan és line scan kamerákat. Az area scan kamerák egy időben egy pixelterületet rögzítenek, a line scan kamerák esetén a képrögzítés sorról sorra történik, ezáltal egy gyorsabb adatgyüjtést biztosítva. Ez a módszer további feldolgozási feladatokat követel meg a rögzített képpontsorok egymáshoz illesztéséhez, a kép felépítéséhez. A line scan kamerák olyan alkalmazásokban előnyösek, ahol a vizsgált objektum mozgást végez, például egy szállítószalagon [6].

A képrögzítési módszert tehát az adott alkalmazás és a jelenet tulajdonságai szerint választjuk ki. Azért célszerủ a tervezés első lépéseiben meghatározni, mert a világítási technika tervezésénél a képrögzítési módszer egy alapvető szempont. Area scan kamerák megvilágításánál a világítóegység geometriai kialakítása is fontos szempont, line scan kameráknál a fényforrás fotometriai tulajdonságaira kerül nagyobb hangsúly.

\subsubsection{Képérzékelök}

Leggyakrabban kétféle szenzortípust alkalmaznak gépi látás rendszerekben, CCD (Charge-Coupled Device - töltéscsatolt eszköz) és a CMOS (Complementary Metal Oxide Semiconductor - komplementer fémoxid félvezető) érzékelőket. A CCD és CMOS érzékelők feladata, hogy a külvilág felől a kamera objektívjén keresztül érkező fényt digitális jelekké alakítsák. A CCD érzékelők pixeleit rendszerint MOS kondenzátorok alkotják, amelyekben az expozíció során a foton abszorpció által generált elektronok tárolódnak [7]. Ez az elektronikus alkatrész alapjában véve egy analóg léptetőáramkör (shift regiszter), amely az elektronikus töltéseket továbbítja. A legtöbb gépi látás rendszerben CCD szenzoros kamerát alkalmaznak [8].

A CMOS érzékelőkben az egyes pixeleket fotodiódák építik fel. Minden egyes pixelhez hozzárendelhetők elektronikus alkatrészek, például tároló cellák, tranzisztorok vagy erősítők, ezért az érzékelöket aktív pixel szenzoroknak nevezik [7]. Ez az időkritikus alkalmazásoknál lehet hasznos, ahol a képnek csak egy bizonyos része lesz releváns. A CMOS érzékelök előnye a CCD szenzorokkal szemben az alacsonyabb elöállítási költség és kisebb fogyasztás, mellyel a CCD érzékelöket fokozatosan kiszorítják a piacról.

\subsubsection{Kamerainterfészek}

Az analóg kamerák esetén a kimeneti videójel egy folytonosan változó feszültségjel. Elterjedt analóg interfész szabványok például az RS-170, NTSC, CCIR és a PAL. Gépi látás rendszerek esetén leggyakrabban digitális kamerákat alkalmaznak [8], melyek a képet digitális adatként továbbítják a feldolgozóegység felé. A legelterjedtebb digitális kameráknál alkalmazott interfészek a Camera Link, az USB 3.0, a GigE Vision és IEEE 1394 szabványok, továbbá a nem szabványos párhuzamos interfész.

Az USB 3.0 előnye, hogy Plug and Play és az összes modern operációs rendszer támogatja. Kifejezetten gépi látás feladatokhoz készült és tudományos eszközök, kamerák, kábelek támogatják a Camera Link interfész szabványt. A GigE Vision szabványt nagy teljesítményü ipari kamerákhoz fejlesztették, a nagy sebességü videótartalom Ethernet-hálózaton keresztüli átviteléhez nyújt keretrendszert.

Az IEEE 1394 szabvány egyszerủ daisy chain (láncba füzött) kábelezést tesz lehetővé [5] lassabb adatátviteli sebesség mellett. 


\subsection{A megvilágítás tervezési szempontjai}

A képrögzítő eszköz kiválasztása után alaposan meg kell fontolnunk, hogy milyen fényforrást és megvilágítási technikát alkalmazzunk a rendszerben. A megfelelő minőségü világítás biztosítása érdekében figyelembe kell venni a fény hullámhosszát, terjedési szögét, intenzitását, meg kell terveznünk a világítóegység kialakítását és elhelyezkedését a kamerához képest.

A megfelelő világítás a kamerás vizsgálatok egyik nélkülözhetetlen eleme, inhomogenitása nagymértékben befolyásolja a gépi látást alkalmazó vizsgálati módszer pontosságát és robusztusságát. Egyre több tudományos vizsgálat és alkalmazás fókuszában áll a megvilágítás, amellyel speciális mérési feladatok is elvégezhetők, világítás kompenzációs technikákat használnak például a talaj felületi érdességének meghatározására [9].

\subsubsection{Fényforrások}

A gépi látás alkalmazásokban leggyakrabban fluoreszcens, fémhalogén, LED, kvarc halogén és xenon fényforrásokat használnak. Kisebb méreteknél jellemzően fluoreszcens, LED és kvarchalogén fényeket, nagyméretủ alkalmazásoknál, vagy ahol nagyon erős fényforrásra van szükség, xenont és fémhalogént használnak. Kamerás vizsgálatoknál a fény spektrális összetételét is figyelembe kell vennünk a tervezés során, össze kell hangolnunk a fényforrás kimeneti spektrumát a kamera spektrális érzékenységével. A mikroszkópos vizsgálatoknál gyakran egy teljes spektrumú kvarc halogén vagy xenon fényforrást használnak, különösen színes képeken. A monokróm LED fényforrás megfelelő feketefehér CCD kameránál és színes alkalmazásokban is [10].

Ahhoz, hogy optimális világítást alakítsunk ki, figyelembe kell venni a vizsgálat közvetlen környezetét, majd a vizsgált minta és a fény közötti kölcsönhatásokat. A környezeti fény befolyásolhatja a vizsgálat eredményét, ezért ki kell küszöbölünk villanófénnyel, szürővel vagy burkolattal. A minta és a fény kölcsönhatását a minta felületének alakja, a fényforrás elhelyezkedése, a minta és a fény színe is befolyásolja. A különböző anyagok a fény különböző hullámhosszait más-más módon tükrözik viszsza vagy nyelik el. Míg a felület színével azonos színü fények a felületet világosabbá teszik, addig az eltérő színek elnyelődnek és sötétebbé teszik azt [10]. A megfelelő színkeveréssel tehát kontrasztot tudunk képezni a háttér és a vizsgálni kívánt felület között.

Egy tanulmányban [11] ismertetett vizsgálatok szerint a felületi érdesség, a fényesség és a felület színe jelentősen befolyásolják a színállandóságot. A fényes és sima felületek nagyobb színállandósággal rendelkeznek, mint az érdes és matt felületek. A megvilágítás változása vagy az objektum elmozdítása a kamerához képest befolyásolni fogja az objektum színeit és következtetésképp annak felismerését.

\subsubsection{Megvilágítási technikák}

A legelterjedtebb megvilágítási technikák a háttérvilágítás, a diffúz-, az irányított- és a sötétlátóteres megvilágítás.

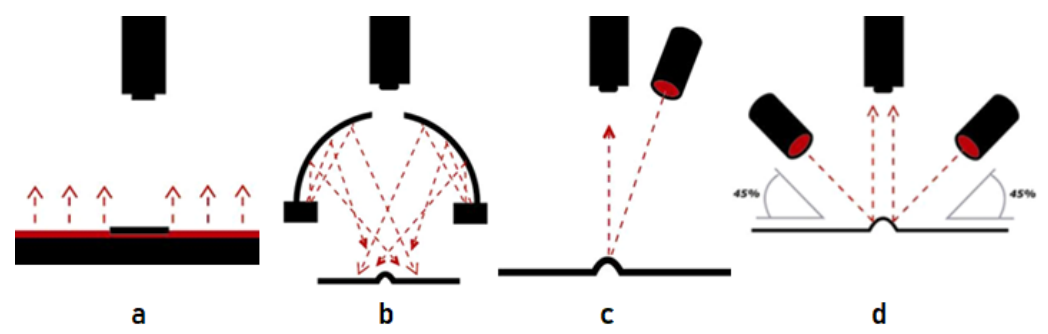

1. ábra. Különbözö megvilágítási technikák [10] 
A háttérvilágítás (1.a ábra) alkalmazásakor a világos háttér előtt lévő alkatrészek sötét sziluettjét vizsgálhatjuk. Előnye, hogy éles kontrasztot hoz létre, mely által az élek detektálása és távolságok mérése könnyen elvégezhető, hátránya, hogy az ívelt tárgyak eltéríthetik a megvilágítás fényét. A diffúz megvilágítást leggyakrabban fényes, visszatükröződő minták esetén alkalmazzák, ahol egyenletes, de többirányú fényre van szükség. Számos megvalósítása ismert, melyek közül a dóm vagy henger és az axiális diffúz megvilágítás a leggyakoribb. A dóm világítás (1.b ábra) ívelt, tükröződő felületek megvilágításakor hatékony [10].

Az irányított (direkt) megvilágítás (1.c ábra) a gépi látás rendszerekben leggyakrabban alkalmazott világítástechnikai megoldás, ahol tipikusan egy pontszerü fényforrásból történik a megvilágítás. Jó választás kontraszt előállításához és a minta felületi jellemzőinek kiemeléséhez. A sötétlátóteres megvilágítás (1.d ábra) alkalmazásakor a nagymennyiségü beeső fény egy tükröződő felületen, amely egyébként csillogó részekkel árasztaná el a képünket, nem a kamera felé, hanem attól eltérő irányba verődik vissza. A kamerába visszaverődő fénnyel pedig egy kisebb jellemző éleit detektálhatjuk, ahol a fényvisszaverődés szöge megegyezik a beesési szöggel [10].

\section{Oktatási célú projektfeladatok gépi látás témakörben}

A negyedik ipari forradalomban egyre jelentősebb szerepet kap a digitalizált gyártáshoz szükséges kompetenciák oktatása. Ehhez megfelelő környezetet biztosítanak a mintagyárak, amelyek a jövőbeli munkaerő számára, a digitalizált termelési környezethez és a kiberfizikai rendszerekhez kapcsolódó technológiák alkalmazásához és integrálásához szükséges készségek fejlesztését teszik lehetővé. Louw és Droomer egy alacsony költségvetésü gépi látáson alapuló minőségellenőrző rendszer fejlesztését mutatta be [12], Leal et al. egy Ipar 4.0 technológiákra összpontosító mintagyárat ismertetnek [13], amely egy számítógépes látáson és gépi tanuláson alapuló minőségellenőrzést is magába foglal.

A tanulmányok emellett rávilágítanak a cselekvés alapú („,learning by doing”) tanulási módszer jelentőségére, amely a gépi látás oktatásában is irányadó lesz számunkra.

\subsection{Kamerák és világítóegységek}

A képrögzítési módszer kiválasztásához és az optikai rendszer tervezéséhez elengedhetetlen a kamerabeállításhoz szükséges paraméterek közötti összefüggések és az area-, illetve line scan technológiák müködésének ismerete. A kapcsolódó elméleti ismeretanyagok tanulmányozását követően kiválasztható az alkalmazáshoz megfelelö, esetünkben USB vagy GigE interfésszel rendelkező area scan vagy line scan kamera. A megvilágítás tervezéséhez segítséget nyújtanak a korábbi évek során készített LED fényforrásokat tartalmazó világítóegységek.
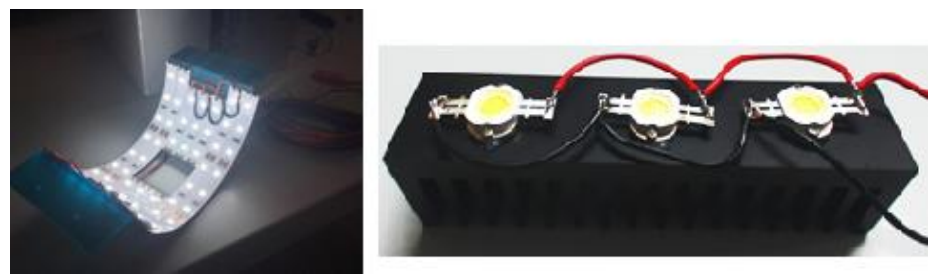

2. ábra. LED világitóegységek

Ívelt felületek megvilágításához és szórt fény előállításához, 3D nyomtatás segítségével készült világítóegység a 2. ábra bal oldalán. A jobb oldali képen látható nagyteljesítményü LED-ek nagy fényigényủ alkalmazásokhoz ajánlottak, ahol a világítóegység geometriai kialakítása kevésbé fontos szem- 
pont, például line scan kamerák esetében. Amennyiben az alkalmazás olyan speciális megvilágítási geometriát követel meg, amely a rendelkezésre álló egységekkel nem valósítható meg, akkor az 3D nyomtatással elóállítható.

\subsection{Alkalmazási példák}

Ebben a fejezetben alapvető gépi látáshoz kapcsolódó feladatok megoldásai kerülnek bemutatásra három példán keresztül, a National Instruments (NI) platformjain. A LabVIEW (Laboratory Virtual Instrumentation Engineering Workbench) az NI mérési, tesztelési és vezérlési feladatok megvalósítására fejlesztett platformja és grafikus fejlesztőkörnyezete. A LabVIEW és megfelelő moduljai az NI beágyazott eszközein közvetlenül futtathatók. Az NI Vision Builder egy interaktív, könnyen kezelhető felületet biztosít a képfeldolgozási feladatokhoz. Használatával az adatgyüjtést és képfeldolgozást egyszerü konfigurációs lépések hozzáadásával valósíthatjuk meg, ami gyors tesztelést tesz lehetővé. Ilyen célokra az NI myRIO-1900 és NI IC-3120 vezérlőegységeket használjuk az Intézetben.

A myRIO egy oktatási célú eszköz, amelyhez USB kamerát csatlakoztathatunk. Az NI IC-3120 egy USB 2.0 és Ethernet portokkal rendelkező ipari vezérlőegység, amelyhez GigE interfésszel rendelkező kamera is illeszthető. Mindkét eszköz egy FPGA-val (Field Programmable Gate Array - programozható logikai kapu-áramkör) és valós idejü processzorral rendelkezik, amelyekre a LabVIEW FPGA Module és Real Time Module segítségével fejleszthetünk. Mindkét eszköz rendelkezik saját be- és kimeneti csatornákkal vezérlési feladatokhoz.

Az első példában a kamerakép rögzítésére javaslunk egy megoldást, a második példában bemutatott rendszer feladata kis alkatrészek azonosítása és áthelyezése, a harmadik példa a LabVIEW és egy PLC alapú demonstrációs rendszer közötti adatcsere kialakításával foglalkozik.

\subsubsection{Streamelés AVI fájlba}

A gépi látás alkalmazások gyakori feladata a képi információ értelmezésén túl a kamera által rögzített képek mentése. LabVIEW fejlesztökörnyezetben az NI Vision Development Module AVI könyvtár funkcióit AVI fájlok olvasásához és írásához használhatjuk. A 3. ábra a kamerakép AVI fájlba mentésének folyamatát szemlélteti LabVIEW környezetben. A kék színü funkciók az IMAQdx paletta elemeit jelölik, zöld színnel az AVI könyvtár elemeit ábrázoltuk. (Az AVI könyvtár elérése a funkciópalettán: Vision and Motion / Vision Utilities / Files / AVI.)

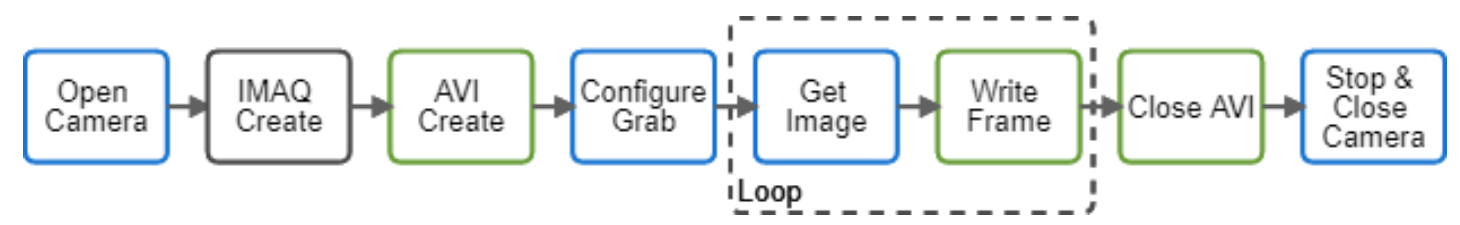

3. ábra. AVI fájlba streamelés folyamata LabVIEW eszközökkel

Az AVI fájlba streamelés első lépései a kamera megnyitása és egy kép létrehozása. Az „IMAQ Create" VI (elérése: Vision Utilities / Image Management) segítségével létrehozott képet a kamera által rögzített képekkel fogjuk a program egy későbbi szakaszában felülírni. A „Get Codec Names” VI megkeresi a számítógépre jelenleg telepített Video Compression Manager (VCM) kompatibilis AVI kodekeket, amelyeket az AVI fájl létrehozásakor kiválaszthatunk. A 4. ábrán látható forráskódban az elérhető kodekeket tartalmazó tömbből az első beépített NI Vision kompatibilis kodeket választjuk ki egy „Index Array” segítségével. Az AVI fájl létrehozását és a képrögzítés konfigurációját egy Start 
gomb megnyomását követően hajtjuk végre. A képi adatok gyüjtését és AVI fájlba írását ciklikusan, a Stop gomb megnyomásáig hajtjuk végre a „Get Image” és „Write Frame” VI-ok felhasználásával.

A ciklusból való kilépést követően bezárjuk az AVI fájlt, majd leállítjuk és bezárjuk a kamerát.

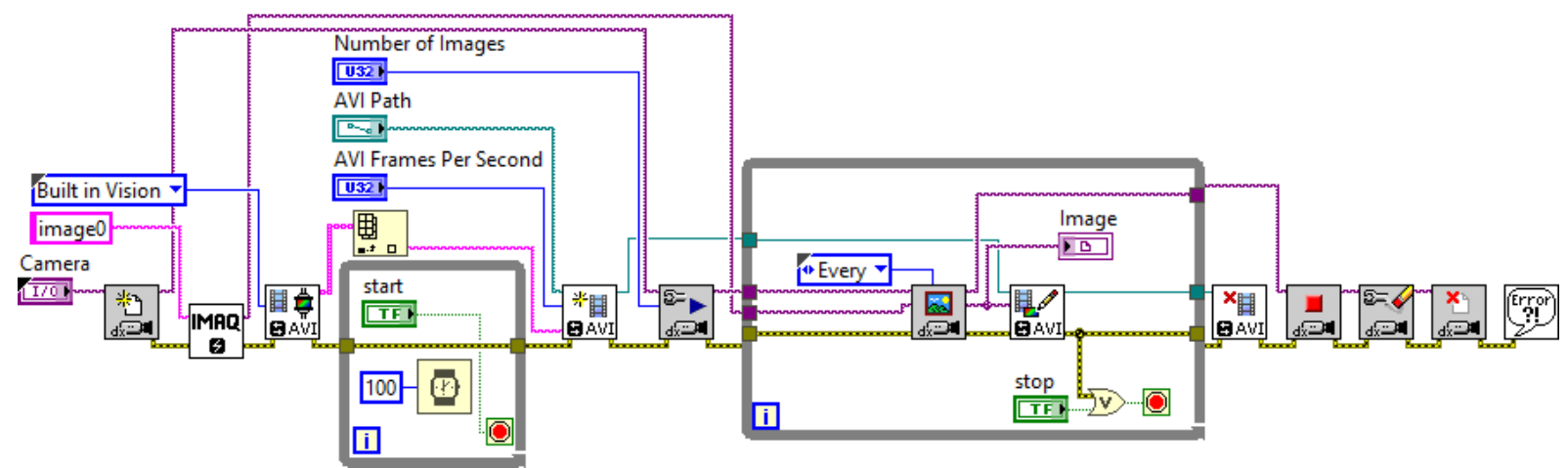

4. ábra. A streamelést megvalósitó LabVIEW forráskód

\subsubsection{Alkatrészek azonositása és áthelyezése robotkarral}

Az ipari robotokkal megvalósított „pick and place” müveleteket kamerás alkatrészvizsgálat előzheti meg. A következőkben bemutatott demonstrációs rendszer fejlesztésével az alapvető gépi látáson alapuló és robotkarral elvégezhető irányítástechnikai feladatok tanulmányozása a célunk. A rendszerben tervezett első kutatómunkában különböző alkatrészek orientációjának és pozíciójának meghatározását, majd annak áthelyezését tüztük ki célul egy robotkarral. A gépi látás alkalmazást Bernát János [14], a robotirányító rendszert Spisák Erik [15] villamosmérnök hallgatók mutatták be a szakdolgozatukban.

A kamerás vizsgálat célja az alkatrészek pozíciójának és orientációjának meghatározása. Az alkatrészek sötétszürke mủanyagból készült, fehér színű feliratos nyomógombok. A megvilágítás kialakítása fontos feladat, mivel a gombok árnyékai megnehezíthetik az objektumazonosítási folyamatot. Az 5. ábra tervezett világítás nélkül, ívelt és irányított világítással mutatja a vizsgált alkatrészeket.

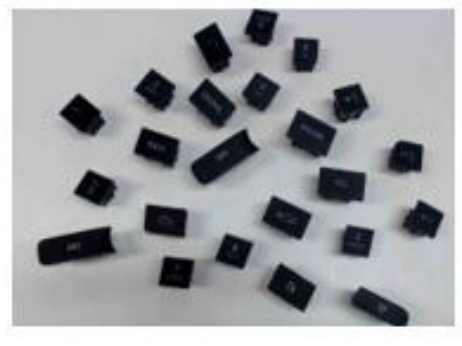

környezeti fény

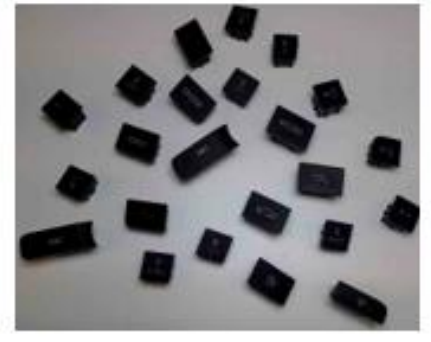

ivelt megvilágítás

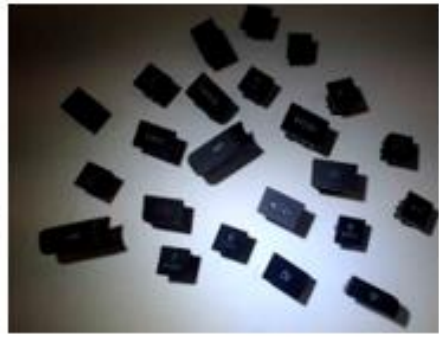

irányított megvilágítás

5. ábra. Különbözö megvilágitások az alkatrészeken

A választott ívelt megvilágítás esetén a tervezett világítás nélkül készült felvételekhez képest nagyobb kontraszttal bírnak az árnyékok, de méretük és zavaró hatásuk a képfeldolgozás során jelentősen csökkent, mely ezenfelül precíz kamerabeállítással javítható.

Az alkatrészek azonosítását és pozíciójuk meghatározását implementáló alkalmazás a Vision Builder (VBAI) felületen készült. Az objektumfelismerést megvalósító osztályozó algoritmus betanult minták alapján dolgozik, a feladatunk ezek helyes megválasztása és a tanulási algoritmus paramétereinek megfelelő beállítása. A konfiguráció alapja egy .clf kiterjesztésủ Classifier (osztályozó) fájl, amit 
a vizsgálati lépésben létrehozhatunk, illetve módosíthatunk. Az optikai karakterfelismeréshez szintén használhatunk VBAI modulokat, például a „Read/Verify Text” lépést. A mérés és azonosítás után az adatok megjelenítése és továbbítása is a feladatunk. Kezelőfelületet a „Custom Overlay” lépéssel készíthetünk, melyen megjeleníthetjük a korábbi vizsgálati lépések eredményeit. A 6 . ábrán látható megvalósított kezelőfelület a beazonosított alkatrészek képét és a kiszámított adatokat (felirat, pozíció koordináták, orientáció) tartalmazza. Amennyiben a rendszer nem ismeri fel az alkatrészt, egy hibaüzenetet küld a kezelöfelületre.

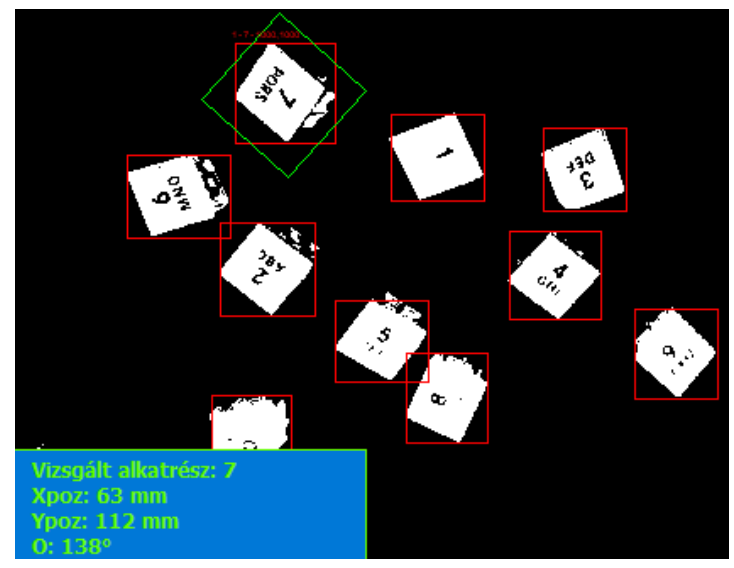

6. ábra. Az alkalmazás felülete sikeres mérés és azonositás esetén

A fejlesztés második része az Arexx RA1-PRO oktatási célú robotkar irányítása a képfeldolgozás eredménye alapján. Ehhez az első feladat a robotkart mozgató 6 szervomotor vezérlőjeleinek meghatározása a robotkar vezérlőpaneljén lévő szervovezérlő jelek mérésével. A 7. ábrán az egyik szervomotorra kiadott legnagyobb kitöltési tényezőjü PWM jel vizsgálata látható WaveForms szoftverben.

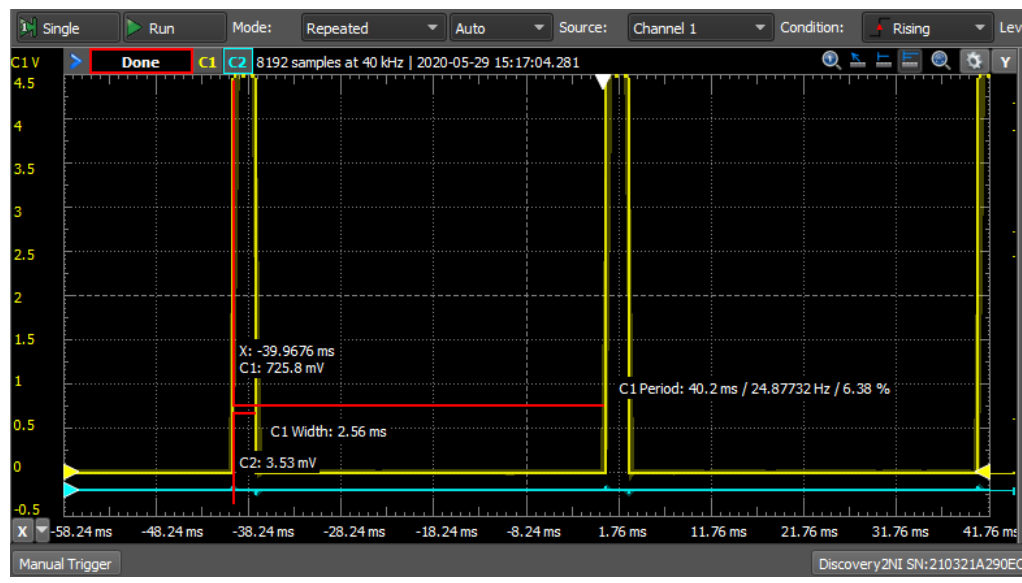

7. ábra. Szervomotorok vezérlöjeleinek mérése

A mért impulzusszélességek alapján a PWM jelek az NI myRIO digitális kimeneti csatornáin elóállíthatók, a motorok tápellátása a robotkar vezérlőpaneljáról is biztosítható. A robotkar megfelelő szervoinak mozgatása a célkoordinátába LabVIEW szoftverben, állapotgép tervezési minta szerint készült el. A robotcsuklók elérendő szögértékeit szögfüggvények alapján számítja ki az algoritmus. 


\subsubsection{Adatcsere PLC alapú irányítórendszerekkel}

Irányítórendszerek közötti adatcserére számos kommunikációs megoldás közül választhatunk. Fontos, hogy az Ethernet elterjedése miatt a mai ipari vezérlőegységek jelentős része alkalmas Modbus/TCP protokoll szerinti adatcsere megvalósítására. Egy készülő diplomamunka témája az Intézetben lévő Festo MPS PLC alapú demonstrációs rendszer kibővítése kamerás vizsgálattal. A képrögzítés és képfeldolgozás LabVIEW szoftverben készül, a kiértékelt adatok a PLC rendszer számára Modbus/TCP-n kerülnek továbbításra.

A LabVIEW Modbus Master és Modbus Slave könyvtárai felhasználásával elkészült egy felület kommunikáció tesztelésére. A 8. ábrán a Modbus Master teszt VI felülete látható. A felületen a kétállapotú és numerikus adatok írására és olvasására van lehetőségünk a megadott regisztercímeken.

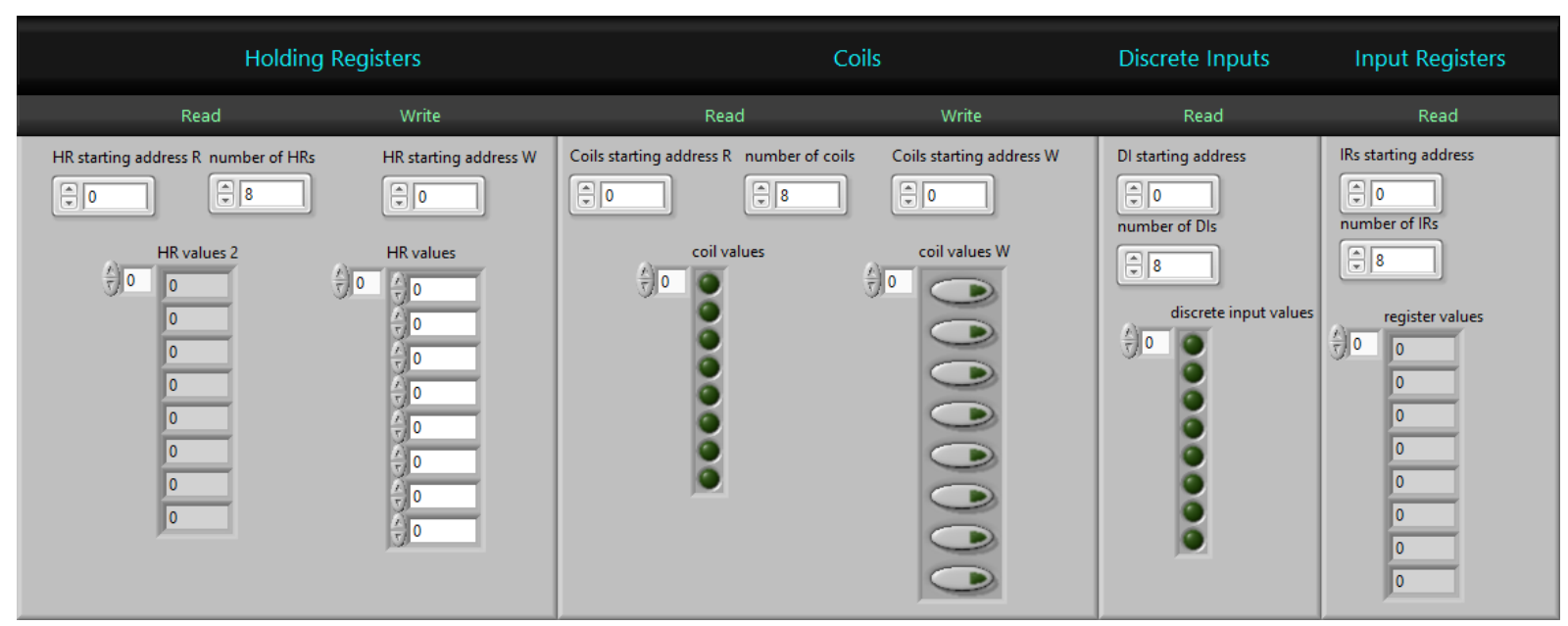

8. ábra. LabVIEW kezelöfelület Modbus Master teszteléshez

A Festo MPS rendszer vezérlési feladatait egy Wago PFC100 PLC végzi el. A kommunikáció konfigurálása a PLC oldalán a Modbus könyvtári funkcióblokkokkal történik. Modbus/TCP szerver konfigurációnál a TCP port címmel, a Master oldalon port és a hoszt IP címének megadásával azonosítjuk a kommunikációban résztvevő állomásokat.

\section{4. Összefoglalás}

A negyedik ipari forradalomban egyre fontosabb szerepet kapnak a gépi látáson alapuló eljárások az ipar számos területén. A cikk elsőként a gépi látáson alapuló rendszerek tervezési szempontjait, a képrögzítéshez és a megvilágítás kialakításához szükséges alapismereteket foglalja össze. A 3. fejezetben alapvető gépi látáshoz kapcsolódó feladatok megvalósítására teszünk javaslatot három oktatási célú alkalmazáson keresztül.

\section{Köszönetnyilvánítás}

A kutató munka az Európai Unió és a magyar állam támogatásával, az Európai Regionális Fejlesztési Alap társfinanszírozásával, a GINOP-2.3.4-15-2016-00004 projekt keretében valósult meg, a felsőoktatás és az ipar együttmüködésének elősegítése céljából. 


\section{Irodalom}

[1] Introduction to machine vision - A guide to automating process \& quality improvements, Cognex Corporation, USA, 2016

[2] Zancul, E., Martins, H. O., Lopes, F. P., da Silva Neto, F. A. T. V.: Machine vision applications in a learning factory, Procedia Manufacturing 2020, 45:516-521. https://doi.org/10.1016/j.promfg.2020.04.069

[3] Alonso, V., Dacal-Nieto, A., Barreto, L., Amaral, A., Rivero, E.: Industry 4.0 implications in machine vision metrology: an overview, Procedia Manufacturing 2019, 41:359-366 https://doi.org/10.1016/j.promfg.2019.09.020

[4] Golnabi, H., Asadpour, A.: Design and application of industrial machine vision systems, Robotics and Computer-Integrated Manufacturing 2007, 23:630-637 https://doi.org/10.1016/j.rcim.2007.02.005

[5] LabVIEW Machine Vision and Image Processing Online Course, National Instruments Inc., Austin, Texas

[6] Imaging Electronics 101: Camera Types and Interfaces for Machine Vision Applications, Edmund Optics Inc.

[7] Helmers, H., Schellenberg, M.: CMOS vs. CCD sensors in speckle interferometry, Optics \& Laser Technology 2003, 35:587-595 https://doi.org/10.1016/S0030-3992(03)00078-1

[8] Labudzki, R., Legutko, S., Raos, P.: The essence and applications of machine vision, Tehnicki Vjesnik 2014, 21:903-909, ISSN 1848-6339

[9] Jibin, G. J., Arunachalam, N.: Illumination compensated images for surface roughness evaluation using machine vision in grinding process, Procedia Manufacturing 2019, 34:969-977 https://doi.org/10.1016/j.promfg.2019.06.099

[10] A Practical Guide to Machine Vision Lighting, National Instruments Inc., 2019

[11] Kumar, V., Kumar, C. P. S.: Investigation of the influence of coloured illumination on surface texture features: A Machine vision approach, Measurement 2020, 152. https://doi.org/10.1016/j.measurement.2019.107297

[12] Louw, L., Droomer, M.: Development of a low cost machine vision based quality control system for a learning factory, Procedia Manufacturing 2019, 31:264-269 https://doi.org/10.1016/j.promfg.2019.03.042

[13] Leal, L. F., Fleury, A., Zancul, E.: Starting up a learning factory focused on Industry 4.0, Procedia Manufacturing 2020, 45:436-441 https://doi.org/10.1016/j.promfg.2020.04.049

[14] Bernát, J.: Alkatrészek poziciójának és orientációjának meghatározására alkalmas gépi látáson alapuló rendszer megvalósitása, szakdolgozat, Miskolci Egyetem, 2020

[15] Spisák, E.: Oktatási célú robotkar irányitására alkalmas rendszer megvalósitása és illesztése gépi látáson alapuló rendszerhez, szakdolgozat, Miskolci Egyetem, 2020 